\title{
Diagnosis and management of hypercalcemia associated with silicone-induced granuloma
}

1. Department of Nephrology and Hypertension, Al-Zahraa University Hospital, Beirut, Lebanon 2. Department of Neurological Surgery, Feinberg School of Medicine, Northwestern University, Chicago, IL 60611, USA

\begin{abstract}
SUMMARY
Hypercalcemia associated with silicone-induced granuloma is a rare disease. Diagnosis can be tricky as it is established after ruling out other hypercalcemia-causing entities. In addition, management is customized depending on the patient's wishes and possible solutions. We present a male bodybuilder, in his thirties, with multiple silicone injections in his upper extremities, who developed hypercalcemia and urinary symptoms. Advanced laboratory tests ruled out various causes of hypercalcemia and CT imaging revealed nephrocalcinosis. A biopsy of the upper arm showed granulomatous tissue and inflammation. The patient necessitated two sessions of dialysis and corticosteroids were given to relieve symptoms and reverse laboratory abnormalities. Silicone-induced hypercalcemia should be on high alert because of the increasing trend of body contour enhancements with injections, implants and fillers. Treatment should be optimized depending on the patient's needs and condition.
\end{abstract}

KEYWORDS: Hypercalcemia. Nephrocalcinosis. Dialysis. Granuloma. Resistance training. Silicones/adverse effects. Injections, intradermal/adverse effects.

A 34-year-old Caucasian male bodybuilder with a history of silicone injections in the shoulders, arms and forearms presented for recurrent left flank pain, dysuria and intermittency for the last 3 months (Figure 1A). He was admitted for the treatment of a urinary tract infection. Lab findings showed hypercalcemia of $13.2 \mathrm{mg} / \mathrm{dl}$ (normal range 8.6 - 10.3) and increased creatinine level of $2.3 \mathrm{mg} / \mathrm{dl}$ (normal range $0.7-1.36$ ). An abdominal CT scan showed bilateral nephrocalcinosis. Intravenous hydration was started, and the patient necessitated two sessions of dialysis. Hypercalcemia workup ruled out hyperparathyroidism, Vitamin D intoxication, hyperthyroidism, malignancy, sarcoidosis and multiple myeloma. A biopsy from the right triceps tendon showed fibrosis and sclerosis granulomas (Figure 1B: 1), active granulomas with giant cells (Figure
1B: 2), and fibrous backgrounds with histiocytes (Figure 1B:3). Magnification with the polarizer showed birefringent bodies corresponding to persistent silicone particles in the tissue (Figure 1C).

Findings supported a diagnosis of hypercalcemia associated with silicone-induced granuloma. Surgical removal of the silicone deposits was not an option. He was started on oral corticosteroids, $40 \mathrm{mg}$ daily for 3 weeks, and was tapered by $5 \mathrm{mg}$ weekly afterwards. Calcium and Creatinine levels gradually returned within range, and symptoms resolved. A repeat blood test, 1-month post treatment showed a Calcium level of $9.1 \mathrm{mg} / \mathrm{dl}$.

Hypercalcemia associated with silicone-induced granuloma is a rare entity with scarce literature. When hyperparathyroidism and malignancy are 


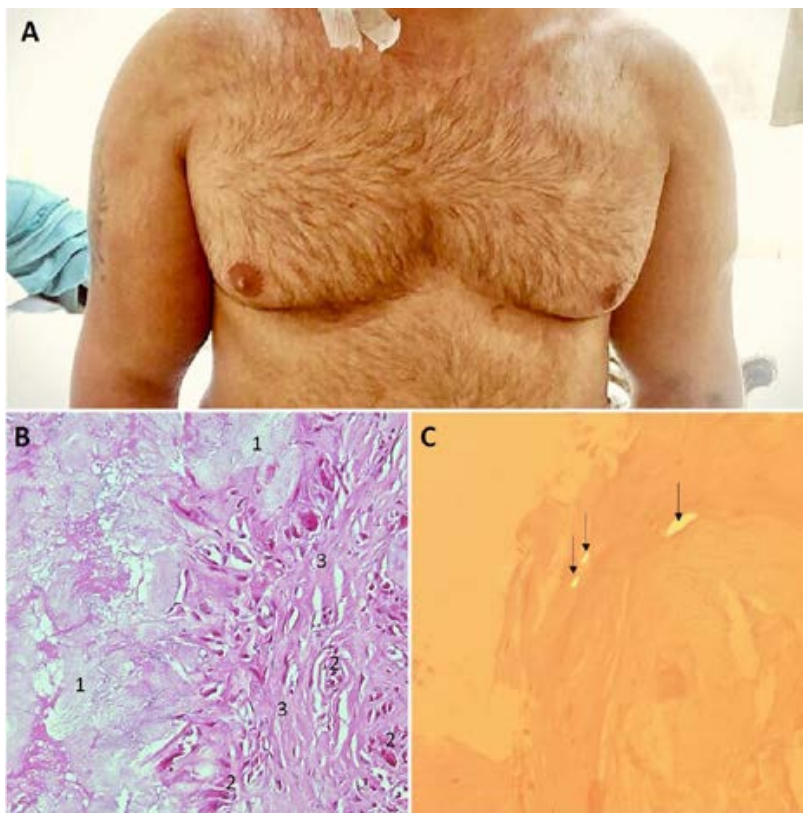

FIGURE 1

ruled out, rare causes of hypercalcemia, which account for less than $10 \%$ of cases of elevated serum calcium, need to be entertained'.

The first case of silicone-induced granuloma was reported in 1964 by Winer et al. ${ }^{2}$. Generally, incidence of granulomatous inflammation in individuals injected with medical grade silicone can reach $20 \%{ }^{3}$
Therefore, physicians and public health personnel should educate individuals interested in pursuing such procedures on the possible risks and complications.

The patient necessitated two sessions of dialysis to reverse his lab abnormalities. Similar approach has been adopted in another patient. ${ }^{4}$ Urgent dialysis can be lifesaving as bisphosphonates need time to optimize their efficiency.

Resection of the silicone is often problematic. Many surgeons deem excision unsafe and ineffective due to the extent of injections with partial migration. ${ }^{1}$ Others, however, opt to resect the granulomatous tissue and it reportedly resolved the silicone-induced hypercalcemia. ${ }^{5}$ The patient's wishes should also be respected, and the physician should make sure to explain the risks and complications of each intervention to maintain a healthy physician-patient relationship. ${ }^{6}$

Physicians should be alert, and have a high index of suspicion for silicone-induced hypercalcemia considering the growing popularity of cosmetic silicone in body contour enhancement.

Ethical Approval: Patient granted full permission to share and publish all information present.

Conflict of Interests: None declared.

\section{RESUMO}

A hipercalcemia associada ao granuloma induzido por silicone é uma doença rara. O diagnóstico pode ser complicado, pois é estabelecido depois de eliminadas outras entidades que causam hipercalcemia. Além disso, o gerenciamento é personalizado, dependendo dos desejos do paciente e das possíveis soluções. Apresentamos um fisiculturista masculino, com trinta e poucos anos, múltiplas injeções de silicone nas extremidades superiores, que desenvolveu hipercalcemia e sintomas urinários. Testes laboratoriais avançados descartaram várias causas de hipercalcemia e a imagem da TC revelou nefrocalcinoses. Uma biópsia da parte superior mostrou tecido granulomatoso e inflamação. O paciente exigiu duas sessões de diálise e foram administrados corticosteroides para aliviar os sintomas e reverter as anormalidades laboratoriais. A hipercalcemia induzida por silicone deve estar em alerta elevado devido à crescente tendência de aprimoramentos do contorno corporal com injeções, implantes e enchimentos. O tratamento deve ser otimizado de acordo com as necessidades e condições do paciente.

PALAVRAS-CHAVE: Hipercalcemia. Nefrocalcinosis. Diálise. Granuloma. Treinamento de resistência. Silicones/efeitos adversos. Injeções intradérmicas/efeitos adversos.

\section{REFERENCES}

1. Agrawal N, Altiner S, Mezitis NH, Helbig S. Silicone-induced granuloma after injection for cosmetic purposes: a rare entity of calcitriol-mediated hypercalcemia. Case Rep Med. 2013;2013:807292.

2. Winer LH, Sternberg TH, Lehman R, Ashley FL. Tissue reactions to injected silicone liquids. A report of three cases. Arch Dermatol. 1964;90:588-93.

3. Schwartzfarb EM, Hametti IM, Romanelli P, Ricotti C. Foreign body granuloma formation secondary to silicone injection. Dermatol Online J. 2008;14(7):20.
4. Hamadeh M Fares I, Maatouk K, Darwish M. Hypercalcemia in a bodybuilder with cosmetic silicone injections. N Z Med J. 2018;131 (1473):78-81.

5. Edwards B|, Saraykar S, Sun M, Murphy WA |r, Lin P, Gagel R. Resection of granulomatous tissue resolves silicone induced hypercalcemia. Bone Rep. 2016:5:163-7.

6. Ayoub F, Fares Y, Fares J. The psychological attitude of patients toward health practitioners in Lebanon. N Am J Med Sci. 2015;7(10):452-8. 